\title{
Religious Terminology as Consolidating and Mediating between Ethno-National Groups: A Case-Study of the Arab Communists in Mandatory Palestine and in Israel (1925-1967)
}

\author{
By Maysoun Ershead Shehade*
}

This paper uses a qualitative text analysis to examine the use of religious terminology (RT) as a tool for national engineering and achieving of political gains, by the Arab leadership and activists of the Communist Party in mandatory Palestine and thereafter in the State of Israel. Based on the framework posited by Antonio Gramsci, the paper examines how a group of "organic" intellectuals used religion as a tool for inserting ideas and for influencing the public arena, and presents a typology examining the changing circumstances that dictate the modes and purposes of RT usage. The main conclusion from this study indicates that $R T$ was used in order to achieve legitimacy, presence, and dominance in the Palestinian and Arab ethno-national space, the Arab-Jewish joint space, and the cosmopolitan space identified with communism. RT seems to serve as a consolidating and mediating tool in and between the three spaces.

Keywords: Religious Terminology (RT),Communist Palestinian Arabs in Israel, National Engineering Tool, Marxism and Religion, Organic Intellectuals.

\section{Introduction}

In general, it can be said that the connection between religion, communism, and nationalism was always present in the Arab world. Most communist political activists in the Arab states have their roots deeply entrenched in religious culture. The leaders of the Arab left wing are mostly Muslim believers, and most leaders who were defined as socialists demonstrated loyalty to socialism that draws its ideas from Islam. For this reason, they tried to formulate a certain type of "Arab socialism", which integrated Marxist ideas and Islamic Arab National foundations (Ginat 2008). Not only Muslim, but also Jewish and Christian political leaders and activists opened the door to communism, primarily because they found it a practical way of implementing the idea of social justice, idea concept that is well anchored in religious tenets (Froese 2004, 2005, Ginat 1996).

The Communist parties in Palestine, Egypt, Syria, Lebanon, and others were founded only after these countries transitioned from Ottoman rule, which lasted about 400 years, to the British and French Mandates (in 1918, following the Sykes-Picot agreement) and soon after gained independence. Although the Communist parties in Iraq and Sudan were the largest Arab parties in their respective countries, neither they nor other Communist parties within Arab states managed to maintain power. It seems that the main reason for the failure of the

*PhD Candidate, Department of Political Science, Bar Ilan University, Israel. 
Arab Communist parties to achieve political power was their disability to link religion and communism by constructing a local doctrine adapted to the national, social, class, and especially cultural circumstances of the region (Abu Khalil 2009).

Religious terminology (RT) was used by Arab communists as a tool, with which to influence the masses. Even if the goal of RT users is attaining political and social gains, there is no doubt that they do so when motivated by the system of religious beliefs from which they emerged (McClelland 1966, Wright 1978, Baldwin 1989). Use of RT is employed in the knowledge that its power lies in bearing stable, unchallengeable, "Divine" content, and that it has enormous ability, more than any other instrument, to strike emotional and sentimental chords (Appleby 2012). Nonetheless, the use of RT by politicians is not something that is utilized freely and with no restrictions. It has its own rules and limits: (a) Use of RT might become a "double-edged sword" against users; leaders who rely on religious legitimacy or who utilize RT are more exposed to criticism directed at them by other actors who try to undermine their religious legitimacy or reply with a counter-religious message that could weaken their position; (b) A discourse that includes RT is only effective among those with similar religious beliefs. When the religious beliefs differ, the legitimacy and RT lose their effectiveness; (c) The $\mathrm{RT}$ of politicians with a religious, moral, and pious reputation produce more benefits (positively effects) than those of politicians who lack such reputation; (d) RT do not hold equal effect; in other words, not every use of RT is beneficial; the impact of RT on the political opinions of community members is limited and affiliated with the speaker's personality and with the importance and content of the RT use (Fox 2018, Fox and Sandler 2004).

This paper examines the motives and purposes of using Religious terminology (RT) by Arab communists in Mandatory Palestine and later in the State of Israel. The Palestinian Communist Party underwent many upheavals during the period of the British Mandate over Palestine; over this period, it was alternately a Jewish mono-national party; a bi-national Arab and Jewish party; separated into two mono-national parties, one Arab and one Jewish; and after the establishment of the State of Israel, unified once again as a binational party. The paper will try to answer the following questions:

a) Under which circumstances could the Arab communists in Mandatory Palestine and in the State of Israel use RT?

b) For what purpose was RT used by the Arab communists in Mandatory Palestine and in the State of Israel?

c) How could the Arab communists in Mandatory Palestine and in the State of Israel use RT when the ideology they preached was stained by atheism?

The following section will present a review linking religion and the Marxist approach, and then a historical path dependent review of the Palestinian Communist Party during the British Mandate and after the establishment of the State of Israel. 


\section{Literature Review}

\section{The Marxist Approach and Religion}

Even before the publication of the Communist Manifesto, Marx succeeded in implanting an ambivalent display regarding the role of religion, stating that: "Religious suffering is, at one and the same time, the expression of real suffering and a protest against real suffering."

In his essays on Hegel's philosophy (1844), and probably influenced by his "teacher" von Feuerbach, Marx introduced a not-truly Marxist viewpoint, in fact a dialectic leftist neo-Hegelian viewpoint, that ambivalently saw in religion alienation, acceptance, and legitimization of the existing conditions, and at the same time a protest against those conditions.

Aside from this ambivalent reference to religion, Marx seldom wrote about religion, and his writings on this subject were published in his early years, the Marxist view towards religion as a social reality became clear. Religion was presented as one of the many forms of ideology - the spiritual production of any people, the conceptual production and of representations of consciousness, which necessarily depend on the production of materials and of parallel social relationships.

Despite the fact that Engels was a materialist, an atheist, and an uncompromising enemy of religion, he showed great interest in religious phenomena and in their historical role. Like Marx, he grasped the ambivalent role of religion, but added and provided an expanded analysis of the relationship between religious representations and the class struggle. It is well-known that in "Ludwig Feuerbach and the End of Classical German Philosophy" (Engels 1886: 366367), Engels dealt with the question of whether God created the world or has the world been in existence forever. He concluded that the answers given by philosophers to this question split them into two great camps. Those who assert the primacy of spirit over nature comprise the idealist camp. The others, who regard nature as primary, belong to the various schools of materialism. Engels, from a Marxist materialist viewpoint, argued that humans are part of nature, and that human thought stems from the material world. In fact, Engels provided a utilitarian and instrumental interpretation of the religious movements, presenting the clerics as a non-homogeneous social group that sometime features in the feudal pinnacle and is sometimes part of the revolutionary peasant movement (see Engels' book, "Socialism: Utopian and Scientific" (1880), in which he indicated the material and concrete interests underlying any affiliation with religion). Both Marx and Engels may be said to have referred to the revolutionism hidden in religion as a phenomenon of the past that has no influence or importance in the modern class struggle. This determination was highly criticized, especially in the camp of Marxist sociologists. Thus, for example, Michael Lowy $(1996,2005)$ and John Molyneux (2008) criticized the fact that the two philosophers did not distinguish between the religious beliefs of people in imperialist countries and the beliefs of oppressed people, and that they did not make sufficient effort to analyze specific 
religious consciousness in order to understand the real human needs and the hidden psycho-social conditions that formed this religious consciousness.

Like Marx and Engels, Lenin maintained the same ambivalent attitude towards religion. In his essay "Socialism and Religion" (1905), he called for the use of rational methods of persuasion and pure ideological logic, using the press and other information materials to combat the exploitation of the masses under the influence of religion and clerics. As we know, Stalin intensified this war against religion, and during his time the Soviet Union knew a difficult history of political atheism (Dawkins 1993). However, as atheism rose so did the voice of small religious movements, until it was discovered that religion was part of the national identity in Gorbachev's time, thus the Orthodox Church took on the status of a public institution, regained control, and reduced the activities of the small religious movements through cooperation with the state (McAnulla 2012).

\section{The Communist Party in Mandatory Palestine and in Israel Historical Path Dependent Review}

Foundations (1919-1925): The roots of the Israeli Communist Party originated in the PKP - the Communist Party of Palestine (in Yiddish: Palestinishe Komunistishe Partei), and the roots of the latter are rooted in the MPS (Socialist Workers Party) that was founded by a group of activists who withdrew from the Poalei Zion (Workers of Zion) movement and its new organization, Ahdut HaAvoda (Labour Unity). This group withdrew because they regarded Poalei Zion as a movement that clung to bourgeois and capitalist elements and renounced its commitment to socialism (Vilner 1970, Dotan 1991). The first conference of MPS, held in Jaffa (in March 1919), was considered the first constituent assembly of the Socialist Workers Party and the First Congress of the Communist Party in Palestine. At this assembly, it was decided that this party would encompass all laborers in Palestine, regardless of their nationality (Jizmati 2015).

Beginning of the Arabization process (1925-1933): Although the Comintern (international union of Communist parties that was controlled by the Soviet Union) was aware that members of the PKP maintained an adequate level of Marxist awareness, and were willing to sacrifice themselves for realization of the revolution, it was suspicious their deviation to the right, their isolation within the "Jewish ghetto", and their contempt for the anti-imperialist spirit, and lacked confidence in the Arabs' ability to join the Communist camp (In 1928, the number of Arab workers in the party was thirty. see: Letter from the Comintern to the executive committee of the PKP, 7.12.1928, in Zehavi 2005: 147, see also Ben Zaken 2006). As a result of these suspicions, the Comintern sent a letter (November 26, 1929), in which it strongly criticized the PKP leadership and instructed them to immediately begin a process of Arabization (Zehavi 2005). Correspondence from the 1930s attests to the removal of Jews from leadership positions and their transfer to advisory positions to the Arab leaders (Najati Sidqi and Mahmud Al-Mughrabi were among the first communist PKP leaders to emerge among the Palestinian Arab population, despite their training, they did not last long in their new roles in the PKP leadership and were deported by the 
British in early 1931. The deportation of the two created a leadership vacuum, see: Kabha 2018), and as a result, many of PKP Jewish members who did not accept the Arabization process left the party.

The process of Arabization (1933-1937): Under the warnings and harsh criticism of the Comintern (see letter from August 27, 1933. see Zehavi 2005 : 304-305) the European Jewish leadership was dismissed and replaced by two Jewish natives of Palestine (Meir Slonim and Simcha Tzabari) and a Palestinian Arab from Jaffa (Radwan al-Hilu). Under their leadership, the party's connection to the Arab increased, and the party was no longer isolated. The Arabization process was opposed by Jewish objectors and Trotskyist advocates. However, this opposition was marginalized with the outbreak of the October 1933 events, following the Wadi al Hawarith lands issue and the ensuing violent clashes between Palestinian demonstrators and British police forces. For the first time in the history of the British Mandate, the anger of the Palestinian masses was directed only against the authorities. The PKP saw these events as an opportunity to ride the anti-imperialist waves in order to strengthen the party's hold on the Arab populace. However, these efforts were unsuccessful due to the presence of national parties that filled the national-political void, the party's underground activities, and its partnership with Jews who were suspected by the Arabs (During the 1920s and until the outbreak of the 1929 riots, the British Mandate operated agents within the PKP in order to ascertain the Party's connections with the Communist International and the Arabs. see: Spiegel 2002).

The presence of Slonim and Tzabari alongside Radwan al-Hilu (at that time, he was also Simcha Tzabari's companion), symbolized an era of "demographic territoriality" and partnership between native Arabs and Jews rather than a colonial immigrant community. Such a reunification pushed aside the national problem and drew attention to the cultural aspect.

The Arab majority in the party's Central Committee (until 1939 the only Jewish committee members were Simcha Tzabari and Meir Slonim) and the joining of new Arab members (Amin Aref and Bulus Farah), completely rejected any right of Jewish settlement in Palestine. The expansion of the Jewish settlement following the Fifth Aliyah (fifth wave of Jewish immigration), Comintern support for violent struggle, the denial of the national right of the Jews, were all factors that widened the schism of national separatism within the party. The rift expanded even further with the outbreak of the 1936-1939 Arab revolt in Palestine, when the PKP presented itself as one of the leaders of the struggle and a supporter of the Arab Higher Committee, while Hebrew leaflets emphasized to give up the option of force so that the Jews would have some peace and quiet (Zehavi 2005: 355369). In fact, these conditions paved the way for the next inevitable stage - the split.

The national conflict that led to a split (1937-1943): After the 1936-1939 Arab revolt in Palestine, the Palestinian communists began to develop a policy that corresponded with the circumstances of their political reality. This was also aided by the Comintern's announcement (in its seventh conference, summer 1935) regarding its abstention from direct interference with the internal organizational problems of each branch. Once the centrality of the Comintern was diminished, 
conflicts immediately emerged between the PKP leaders from the two national groups. The background of the conflict was national and there were many factors that contributed to its eruption. Among these factors we may mention the national alliance with the moderate Zionist parties, initiated by Jewish communists in 1937; the harsh treatment of the Palestinian Arabs by the Mandate government, and at the same time, their lenient treatment of the Jews; the alienation and polarization that began to develop between the two national groups, which escalated in the wake of the Great Arab Revolt of 1936-1939; the national awakening and the development of the idea of a bi-national state on the part of the Jews with the end of World War II, etc. The conflicts continued until 1943 when the party was expelled from the Comintern due to its cooperation with the Histadrut in strikes and demonstrations. This led to the final split.

The split - The National Liberation League in Palestine (1944-1948): After the split, the Arab members of the Palestine Communist Party founded the National Liberation League in Palestine (uṣbat at-taḥrīr al-wațaniyy fi filasțīn). The Jewish members, led by secretary-general Shmuel Mikunis together with Meir Vilner and Esther Vilenska, continued to lead the PKP. In 1944 Simcha Tzabari and Meir Slonim established the Communist Educational Union - later known as the Hebrew Communists, which was a Zionist organization. Additional factions were established and most of these united after the establishment of the State of Israel to form Maki (The Israeli Communist Party) (Miron 2011: 68).

The leaders of the National Liberation League, established in January 1944, initiated Marxist study groups that were initially deployed in urban centers such as Jerusalem, Hebron, Acre, Haifa, and Nazareth. These groups became small cells that were mainly attended by intellectuals who constituted the core of the revolutionary proletarian consciousness (the Avant-garde) according to MarxistLeninist thought. The National Liberation League was formed at a time when Jewish immigration accelerated. This was also a period when the Zionist movement and the Histadrut urged the implementation of two goals: the "conquest of soil" and the "conquest of labor" from Arab hands. The league struggled against the "conquer of soil and labor" but at the same time emphasized its position, which was contrary to that of the traditional national movement headed by Mufti Haj Amin al-Husseini, especially in regard to the forming of relations with the Axis countries (Italy and Germany) during World War II (Al-Ittihad: September 10, 1944) .

The league discussed the Palestinian problem and even issued a detailed memorandum to the UN (in August 1947) in which it insisted that the Jewish problem should not be solved at the expense of the Palestinian problem. It stressed that the Palestinian problem is an issue of independence, of liberation of the land from imperialism and foreign domination. The league noted, in more than one document (see: The National Liberation League in Palestine: 19451948 - Three Historic Documents (2001). Fu'ad Nassar Center. (Ramallah, pp. 84-85), that its political activity will only take the form of unarmed struggle.

It is well-known that the UN resolution on the Partition Plan for Palestine (November 29, 1947) was adopted in the General Assembly with the surprising support of the Soviet Union. Since then, and throughout the 1948 Independence 
War, the league embarked on a campaign to persuade the Arab residents to agree to the Partition Plan; it also called upon Arab residents to hold onto the land and expel the Arab armies from the homeland. In this persuasion campaign, the league relied on the proclamation of Communist parties in Arab states, distributed in early May 1948. Later, when the sight of refugees, deportations, and killing were still evident, the leadership of the league convened (at the end of September 1948) and announced its return to the Israeli Communist Party - Maki.

1948 - onward - a joint bi-national party: After the establishment of the State of Israel, Maki's Jewish character and dominance became prominent: 700 of its 1000 members were Jews, and the party leadership was also entrusted to Jews. Gradually, however, Maki became a political body expressing the national protest of the Arab citizens. A large part of the Arab public identified with Maki because of its vehement opposition to the Zionist idea and its harsh criticism against Israel's policy and martial rule over the Arab population, and due to its platform of finding solutions to the socio-economic problems of the Arab population in Israel. As a political organization that operated within the legitimate framework of the Israeli parliamentary, Maki was able to build itself an image as guardian of the problems of the underprivileged minority. The communist platform on the issue of Arab nationality appealed to a large part of the Arab public in Israel and helped consolidate the party within this population. In May 1965, on the eve of Maki's 15th Conference, the Jewish-Arab partnership was once again divided into two groups: a Jewish faction and a faction that included both Jews and Arabs (the New Communist list - Rakah) .The main factor behind the split was ideological: the Jewish faction adopted a balanced approach towards the JewishArab conflict and recognized the existence of two national movements in the region (Zionist and Arab), while the opposing faction adopted a distinct pro-Arab approach. After the elections in November 1965, it became clear that Rakah had won three Knesset seats versus the searing defeat incurred by Maki, which won only one seat. The Israeli communist camp was split along ethnic lines: the Arab voters gave Maki less than 5\% of their votes, while $85 \%$ of them voted for Rakah. During this period, Rakah was the main factor in the political leadership of the Arab citizens of Israel. Rakah leaders were the main proponents of the Land Day demonstrations in 1976 and of its organization. They were those who led to the establishment of the Democratic Front for Peace and Equality (Hadash) in 1975. After 1977, Rakah was part of Hadash from the 9th to the 12th Knesset elections. In 1989 it changed its name again to Maki and remained part of the Hadash list (Rudinzky 2014).

As we have seen, along the historical path dependent that has been reviewed, the tensions surrounding national identity were the main issue in the history of the relationship between the two national groups (Arab and Jews). These tensions were enhanced by those resulting from the act of taking command and control. 


\section{Methodology}

From a microscopic approach (Laughlin et al. 2000; Lozano et al. 2008), this study examines the discourse of the Palestinian Arab activists and leaders who belonged to the Communist Party prior to the establishment of the State of Israel and continued to belong to it within the Israeli Communist Party. The research group consists of those Arab political leaders, intellectuals, authors, and journalists in the Communist Party who belonged to the political settings of the National Liberation League (1943-1947), Maki, Rakah, and Hadash (from 1948 until the end of the period studied, 1976). The study will relate to this distinct group as a group of public intellectuals who were given the opportunity to represent, embody, and express a message, outlook, approach, philosophy, or opinion to and for an audience (Said 1994).

Based on the framework posited by Antonio Gramsci (1971: 54), the research group is related to as a group of "organic" intellectuals, who similar to other Communists in the Middle East (see, for instance, the cases of Egypt: Ginat 2008, 2011, Iraq: al-Kaysi 2012, Syria, Lebanon and Sudan: Jazmati 2015) used the "politics of the street" as raw material, reformulated and reshaped it, and on this basis created an ideological mass that was presented in the public arena and contributed to the development of civil society and of the national movements (Bamyeh 2012, Said 1994). The study examined: a. the ideas they formulated for their audience (ideas reflecting social feelings and the audience's thoughts and wishes were not explored with regard to this study); b. use of religious messages as a way of influencing the insertion of these ideas.

Based on a qualitative approach that relies on analyzing textual content, which is a technique for the systematic identification of messages in a text and drawing valid conclusions in their broad context (Holsti 1968, Krippendroroff 2004), a thematic analysis and a critical discourse analysis were performed (Shanthi et al. 2015: 159).

Examination of the public discourse focused on "intersections", which are constitutive events related to the Palestinian Communist Party during the British Mandate and after the establishment of the State of Israel.

The analyses focused on opinion columns and articles published in AlIttihad (The Unity), the Communist Party organ in Arabic, between 1943-1967, correspondence between the party members and the Comintern, the Nidal al Shaab newspaper, which was the Party organ in Arabic in the years 1940-1943, and official publications during the period of the party's Arabization process in 19351937, that is, after the appointment of Radwan al-Hilu as secretary-general.

The underlying assumption of critical discourse analysis is that the text reflects the authors' ideological perceptions and, accordingly, the perceptions they wish to promote (Hart 2011). The thematic analysis intended to identify repetitive patterns in the text and to identify the motifs that characterize use of religious messages (Van Dijk 2003). While the critical analysis intended to examine the religious messages themselves, their contents and their targets (their use), special attention was given to linguistic components such as the selected vocabulary, the types of argumentation, metaphors, and images, polarity, 
repetitive use of words, hyperbole (exaggerations), etc. (Van Dijk 2003, Meyer 2001, Wodak 2001).

\section{Findings and Interpretation}

When the party (PKP) was under the control of a dominant Jewish bloc with an Arab minority, there were only few traces of RT by Arab communists (According to a letter dated January 1, 1933, the number of Arabs in the party was 150. see Al-Sharif 2006: 343). One of the many items of correspondence is a letter written in French under the pseudonym "Hassan". The author of the letter is unknown, but the use of French often indicates his identity as a nonArab writer. This letter was sent from the Central Committee of the Palestinian Communist Party on October 7, 1931 (Al-Sharif 2006: 322), and contained harsh criticism directed to the General Islamic Congress in Jerusalem. The congress, which was held to discuss the conditions in the Holy Places and the establishment of an institute for Islamic religion in Jerusalem, was given a reactionary description as intended to serve the British imperial forces. Obviously, this letter is not sufficient to reach a decision concerning the attitude of the Arab communists to religion or their use of RT in that era.

About the period of 1933-1937, during which the Arabization process began, one can learn from a letter of the Palestinian Communist Party to the national parties in Palestine (October 16, 1935). This letter (Al-Sharif 2006: 435), written in fluent Arabic (Unlike the previous period when letters were written in Russian, German, Yiddish, and more, only a few letters were written in Arabic and these were full of spelling and syntax mistakes), began with the Islamic preface "Peace, mercy, and blessings of Allah be upon you". The letter is replete with quotations from the Quran and appears to have been written by an educated Muslim communist who knew and was familiar with the contents of the Quran and was influenced by them. This letter came to the attention of the Communist Party in Syria, raised the wrath of its members, and compelled them to respond with a letter opposing the use of RT. The Syrian communists' protest against this letter can be interpreted as emanating from two main reasons: (a) The knowledge that a writing style filled with religious quotations would annoy the superiors in the Comintern; and (b) The desire to preserve the good relations between the Jewish communists and the communists of the Syrian and Lebanese parties (most of whom were Christians and Armenians, whom the Jewish communists helped establish their parties), as the letter was directed against the Jews in general and not against the Zionists as was customary. Al-Sharif 2006: 439) In response to this criticism, the Palestinian Arab communists replied in a letter to their Syrian party brothers saying that for communists like them, religion is the root of morality and it does not deter them. They explained that their use of RT was done in the knowledge that this terminology would affect the poor, which constitute the majority in Palestine ( Al-Sharif 2006: 440).

This letter leads to two conclusions: (a) The Palestinian communists used $\mathrm{RT}$ to connect with the masses, even if it came at the expense of their relations 
with the Jewish communists or communists in Arab countries; (b) They maintained their identity and demonstrated a high degree of religiosity.

Nevertheless, it seems that the use of RT was very restrained and was employed only in situations where the party sought to expand its influence among the masses. A review of the pamphlets of the party organ, Nidal al-Sha'ab, between 1940 and 1943, when the Arabization process was already established, shows complete abstention from any religious issue or use of religious quotations/ language that does not serve expanding the party influence among the masses. This can be interpreted as an aspiration of the Arab communists (most of the newspaper's writers, headed by the party's secretary-general, were Muslims who had been educated in the traditional Islamic culture) to present themselves as equal to the Jewish camp that was committed to the atheist character of Marxism, and that used no religious language, therefore almost no religious identity was evident among the Arab camp. It should be noted, that the Arab communists' reluctance to give up the religious motifs was not hidden from the eyes of the "atheists" in the Comintern at the time (The Palestinian press of that period reported the closure of two-thirds of the churches in Russia. At the beginning of 1930, 540 churches, 18 mosques, and 63 synagogues were reported closed in a period of two months (see Al-Karmil Newspaper, January 9, 1930). The correspondence between Nadav, the contact person of the Palestinian Communist Party (PKP), who was a Jew, and the Central Committee of the Comintern from March 10, 1930, is one interesting example. In this correspondence, Nadav reports on taking the opportunity when Gazan Muslim communist intellectual Hamdi al-Husseini went on a pilgrimage to Mecca to hold meetings and create contacts with national elements in neighboring countries (Al-Sharif 2006: 260). Tepper (a Jew from the PKP) also discovered that the return of the Hejaz railway to Muslim hands made it possible to send propagandists from Russia to Mecca during the pilgrimage in order to spread propaganda, mainly about class issues such as working hours and the just distribution of lands to peasants (see: letter from March 8, 1927, in Batatu 1978: 386).

Between 1943 and 1948, the party was mono-national, and the Christian members took over the leadership of the National Liberation League. These leaders completed their high school studies at missionary schools(Apart from Bulus Farah and Fuad Nassar, who did not graduate from high school, the other four Christian founders, Hanna Nakara, Emile Touma, Tawfik Toubi, and Emil Habibi graduated from the prestigious Bishop Gobat High School in Mount Zion, Jerusalem). The Christians in Palestine at that time numbered at about $140,000(8 \%$ of $1,750,000)$ and therefore this leadership turned to increased use of RT deriving from Islam, with the aim of (a) blurring Christian religious affiliations; and (b) presenting themselves as contained within the Muslim majority, without giving up their religious identity. The Christian leaders, who were educated intellectuals, were aided by the cultural atmosphere and the local customs and traditions, the literature in which they were raised and educated, and the press, all of which were enriched by an atmosphere that was based on Muslim religious culture. 
Table 1. Use of RT by Historical Periods

\begin{tabular}{|c|c|c|c|c|}
\hline & $\begin{array}{l}\text { Before the } \\
\text { Arabization Process }\end{array}$ & $1935-1943$ & $1943-1948$ & $1948-1967$ \\
\hline Degree of use & Rare & Restrained & Massive & Massive \\
\hline Leadership & Jewish & Muslim secretary general & $\begin{array}{l}\text { A group of Christian intellectual leaders } \\
\text { in the Arab bloc }\end{array}$ & $\begin{array}{l}\text { A bi-national Jewish and Arab party; in the } \\
\text { Arab bloc the leadership was Christian and } \\
\text { later joined by Muslims as well. }\end{array}$ \\
\hline Goal of use \#1 & & $\begin{array}{l}\text { Receiving legitimacy and } \\
\text { competing for leadership } \\
\text { with other national parties. }\end{array}$ & $\begin{array}{l}\text { Integration: blurring the ethnic } \\
\text { (Christian) affiliation and integrating the } \\
\text { Christian minority into the Muslim } \\
\text { majority. }\end{array}$ & $\begin{array}{l}\text { Integration: blurring the ethnic (Christian) } \\
\text { affiliation and integrating the Christian } \\
\text { minority into the Muslim majority. }\end{array}$ \\
\hline Goal of use \#2 & & $\begin{array}{l}\text { Recruiting members from } \\
\text { the poor masses }\end{array}$ & $\begin{array}{l}\text { Legitimacy: removing the demon of } \\
\text { atheism, presenting the Soviet Union as a } \\
\text { liberal power that supports religious } \\
\text { freedom. }\end{array}$ & $\begin{array}{l}\text { Legitimacy: implanting the party as a } \\
\text { national party that grew from the workers' } \\
\text { movement, as opposed to the bourgeois } \\
\text { national movement that ruled before } 1948\end{array}$ \\
\hline Goal of use \#3 & & & $\begin{array}{l}\text { Dominance: A covert competition } \\
\text { between the national and religious leader } \\
\text { Haj Amin al- } \\
\text { Husseini and Stalin }\end{array}$ & $\begin{array}{l}\text { Dominance and control: creating an image } \\
\text { of an impostor and a traitor for the national } \\
\text { and religious leader, Haj Amin al-Husseini. }\end{array}$ \\
\hline Goal of use \#4 & & & $\begin{array}{l}\text { Coronation of a supreme leader: placing } \\
\text { Stalin as the head of a super-power and } \\
\text { as commander of an army that guards the } \\
\text { interests of the Muslims and the } \\
\text { establishment of world justice. }\end{array}$ & $\begin{array}{l}\text { Coronation of the Soviet Union as } \\
\text { bequeathing universal justice and as } \\
\text { fighting the reactionary dominating forces } \\
\text { and the forces of imperialism. }\end{array}$ \\
\hline Goal of use \#5 & & & $\begin{array}{l}\text { Softening and silencing objections on } \\
\text { ethnic or social status grounds within the } \\
\text { party }\end{array}$ & $\begin{array}{l}\text { Justifying the support for the partition } \\
\text { plan and legitimizing the existence of the } \\
\text { State of Israel }\end{array}$ \\
\hline $\begin{array}{l}\text { consolidation } \backslash \\
\text { bridging }\end{array}$ & & $\begin{array}{l}\text { Ethno-national consolidation } \\
\text { and maintaining a bridge } \\
\text { between the two } \\
\text { nationalities. }\end{array}$ & $\begin{array}{l}\text { Ethno-national consolidation: } \\
\text { Palestinian, Arab; Cosmopolitan bridge } \\
\text { to the Muslim space that is connected to } \\
\text { the Russian superpower; Cosmopolitan } \\
\text { lateral bridge to the Communists in the } \\
\text { Soviet Union and its allies. }\end{array}$ & $\begin{array}{l}\text { Consolidation within and bridging between } \\
\text { three systems: the Palestinian-Arab ethno- } \\
\text { national system; the broad system of the } \\
\text { Arab and Jewish binational party; the } \\
\text { cosmopolitan system which identifies with } \\
\text { communism. }\end{array}$ \\
\hline
\end{tabular}


The height of the use of religious language by Arab communists in Mandatory Palestine at the time was embodied in their decision to open the first issue of their newspaper, Al-Ittihad (May 14, 1944), with a headline that was a verse from the Quran - the holy book of Islam(The headline of the first newsletter was taken from Sura Al-Ra'ad, verse 17, and reads "As for the foam, it vanishes, [being] cast off; but as for that which benefits the people, it remains on the earth"). Also, in the festive newsletter of the second year (May 13, 1945), the same verse from the Quran was featured in the editorial headline. Similarly, the opening of their third-year festive newsletter (May 1, 1946), signed by Christian communist Emil Habibi, also had a religious flavor; the second Muslim caliph, Umar ibn alKhattāb, is quoted as swearing to the god of the Kaaba (the holy place in Mecca) to lead his Muslim nation to the safe road.

Careful examination of the newspaper's leaflets (years 1943-1948) indicates that the contents of the articles lacked RT unless it was carrying a democratic sociological value that conformed to the values of communism. In addition, a review of the bulletins easily shows that emphasizing religious identity was a tool by which the Arab communists on one hand kept the atheist demon attached to the communist thinkers and the party leaders at a distance, and on the other hand touched emotional and sentimental chords among the believers sought by the Communist Party. Emile Touma, the Palestinian Christian intellectual from Haifa, can be held responsible for the decision to open the first issue of the Al-Ittihad newspaper with a quote from the Quran. Touma, as the newspaper's owner and editor-in-chief, also chose to report in this bulletin on the visit of the secretary of the Russian embassy in Cairo, Abd al-Rahman Soltanov, to Jerusalem (in May 6, 1944), where he was given a tour of the AlAqsa Mosque and the Supreme Islamic Council. This report had no other purpose than to encourage Muslims to join the party, with the emphasis that the Soviet Union is represented by devout Muslim representatives. This mantra repeated itself in many other reports.

It is interesting to raise one other point that relates to the desire of the Arab communists to emphasize and display the top leadership and the party's philosophers as "prophets" of a just and egalitarian world, while religious leaders have not succeeded in doing so. During the British Mandate, the head of the ruling national leadership, Haj Amin al-Husseini, was both a religious and a national leader. In an ambivalent manner, the Arab communists presented the atheist leader of the Soviet Union - "Stalin", as someone who had been crowned by the Muslim monotheistic believers. The bulletin dated June 8, 1944 brought a letter from the conference that had been sent by the Muslim representatives of Armenia, Azerbaijan, and Georgia to "Marshal Stalin". In the letter, they stressed their love to the motherland and their loyalty to their leader Stalin and called upon all Muslim believers to join the Red Army in its "holy war" against Hitler and the Nazis. It should be noted that, frequently and repeatedly, the communists were not deterred from using biased reports and distorted facts in order to present Lenin and Stalin as the leaders of justice entrusted with world order - especially the order in the Islamic world. The bulletin from January 4, 1945 published Lenin and Stalin's manifest, dated to the period of the Red Revolution and published in the Pravda 
newspaper (December 5, 1917). In this manifest, aimed at Muslims in Russia and in the East, Turkey, India, and other countries, Lenin and Stalin announced that after the revolution the injustice will end, there will be no more destructions of mosques and temples, freedom of belief will not be prevented (as conducted by Tsarist Russia), and national rights will be granted - something that contradicted the truth and the reality.

The league also used RT to silence any opposition to its action. The main article of a bulletin from January 14, 1945, includes a description of a comprehensive conference held for all representative offices of the Arab organizations, committees, and movements in Palestine, in which serious disagreements around the selection of delegates to the International Congress in London were reported. At the end of the conference, an agreement was reached to select three representatives: Sami Taha, who was a Muslim and well connected to the Histadrut and the British government; Hanna Asfur, who was Christian and was chosen with the intervention of the Histadrut; and Bulus Farah, who was Christian and one of the leaders of the National Liberation League. A review of pamphlets related to the conference shows that many of the other representatives protested against the choice of Bulus Farah, both because his religious identity and because of his social status. RT was immediately employed, and from within the league and through its journal it was a Muslim, Muhammad Bader Al-Din alKhatib, who scolded the other Muslim representatives, protesting the selection :"On the pilgrimage to Mecca, where you were all present, you were all in homogenous outfits and in one class, with no difference; you were all equal except for the amount of darkness within you as human beings [...] The evil spirit biases the spirit of a human being so that he can only see the difference between people and not the human unity".

The period after joining Maki in 1948: After the establishment of the State of Israel and after the communists joined the Israeli Communist Party (Maki) in late September 1948 (see declaration in Al-Ittihad: October 18, 1948), three factors were added that led the communists to use religious language: The agreement on the Partition Plan despite their strong opposition to it before the party supported the resolution; The agreement to grant the right of self-determination in the form of a state for the two nationalities, without considering the consequences of such recognition; The establishment of the Jewish state (Israel) and the nonestablishment of the Palestinian Arab state. These three prominent factors forced the Palestinian communists to be present as consolidating agents within their ethno-national sub-system, while at the same time as mediators within the broad system of the bi-national party. In and between the two systems, RT was used as a consolidating tool and/or as a mediating tool. Within a short period of time, the Arab party members became part of the United Party (Maki) and were joined by immigrant Jews who came from Arab countries, mainly Iraq, who spoke and wrote in Arabic and soon became partners in decisions about contents published in the communists party newspaper (see Kabha 2006 2018). At that time, Al-Ittihad also served and connected the Jewish immigrants who came from Arab countries and who had not yet mastered the Hebrew language. 
Use of RT in the period of 1948-1967 now had new goals. (a) Emphasizing the pan-Arab sentiment, embraced by the Russian superpower; (b) Mediating between Arabs and Jews under a cosmopolitan communist identity; (c) Granting legitimacy to the State of Israel; (d) Bypassing a direct confrontation with forces from the Jewish right-wing and joining forces with the Jewish left-wing. These sub-goals can be grouped together to form one overall purpose: The use of religious terminology (RT) as a consolidating tool in and between the three systems: the Palestinian Arab ethno-national system; the broad system of the binational party; and the wide cosmopolitan system headed by the Soviet Union.

Immediately after joining Maki (Emil Habibi's speech on October 22, 1948), the communists in leadership positions, mostly Christians, made sure to highlight their movement as a national liberation movement whose leadership had grown from the ranks of the working class, while presenting the Palestinian national leadership before 1948 as a bourgeois movement that had taken control of the people. Now that the dominant traditional national leadership from before 1948, mostly Christians as well, was outside the borders of the Jewish state, leaving the political and national space almost empty, the experienced communists immediately took a stand and placed themselves as responsible and as speakers on behalf of the Arabs who remained within the borders of the State of Israel. They used RT to assume the position of national patrons, in order to justify their consent to the Partition Plan, as opposed to the disaster inflicted upon them by the Mufti, who had joined Hitler and refused to agree to it (Al-Ittihad: March 10, 1967). Regarding the national disaster and loss of the homeland that had befallen their people, the Arab communists now connected with the Jewish camp within the party, made sure not to place any responsibility on the newly established Jewish state, and instead blamed the reactionary forces of Anglo-American imperialism and the Arab states that had allied with them (Al-Ittihad: November 8, 1948).

As in the previous period, the Arab party leaders of the Israeli Communist Party tried to distance themselves from the ethnic affiliation and from their connection to the church. In the first page of the November 1948 bulletin, we can find the Arab communists' strong opposition to the joining of the Clergy from all Christian communities for the establishment of the Nazareth Workers' Union that organized workers according to their communal affiliation. The communists continued to highlight this issue in the following bulletins as well, criticizing religious leaders and questioning their integrity and efforts (Al-Ittihad: October 25, 1948). In order to emphasize the distancing of the ethnic demon, the communists also elaborated on the rumor that the city of Nazareth, similar to Jerusalem, would become an area under international supervision because it is a holy city for Christians (Al-Ittihad: December 26, 1948):

\footnotetext{
"The transformation of Nazareth (according to the Partition Plan, was to be part of the Arab state) into an international zone puts it under the control of Anglo-American imperialism. [...] The relations between the residents will be based on ethnic and religious discrimination and there will be a separation between Nazareth and the surrounding villages [...] We are fighting for the establishment of an independent and democratic Arab state, of which Nazareth will be part".
} 
However, avoidance of identifying with the Church had not always been maintained, especially when it served the interests of the communists themselves. For example, the party's newsletter emphasized the restoring of relations between the Orthodox Church in Palestine and Israel and the Soviet Union. In this case, religious faith connected the three entities: the Palestinians in Israel and in the area that was under the control of Jordan and Egypt, the State of Israel, and the Soviet Union (Al-Ittihad: December 13, 1948).

The Arab communists in Israel continued to portray the superpower as a guardian of religious freedom and the holy places, and as very far from atheism. More than once, they emphasized the visits of Russian Muslim clerics on their pilgrimage to Mecca, and also their visit to Egypt and the surrounding Arab countries (" see, for example, Al-Ittihad: Bulletin from September 23, 1955). There were also reports of Christian Arab delegations attending congresses held in the territory of the Russian superpower, who used their visits to attend Sunday and public services in the Russian Orthodox churches. Thus, for example, there was a report of a visit of a delegation from Israel in a cathedral in Sofia, capital of the People's Republic of Bulgaria, on October 28, 1955, and on gifts that were given by the Bishop to the Orthodox Church in Nazareth.

A review of texts in the newspapers reveals that $\mathrm{RT}$ played a role in legitimizing the existence of the State of Israel and in calling upon Arabs in the surrounding countries to maintain peaceful relations with it. The October 18, 1955 bulletin included an article with the heading:

"Cairo - One of the reporters asked a senior official in the Islamic al-Sharia, sheikh Abd al-Wahhab Khalaf, whether the laws of Islam prohibit a peace agreement with Israel, and the sheikh replied in the negative".

The above news gives some legitimacy, coming as it did from a leading country where nationalism and Arabism were flourishing under the patronage of Gamal Abdel Nasser, and not only that, it emanates from a city that symbolizes Al-Azhar, which is a respected source of the Sharia - the Islamic legislation.

In circumstances in which national sentiments arose, especially in times of war and direct confrontation between Israel and the Palestinians and/or the neighboring Arab countries, and against the background of the policy of discrimination and oppression by the government towards its Arab citizens, the communists used religious terminology (RT) in order to soften the confrontation and mediate between the Arabs and the Jewish Right, and to mobilize the Jewish Left to support the Arab struggle against the government and its policy. In this context, we may present the example of the Kafr Qasim massacre, carried out by an Israeli Border Police unit on October 29, 1956, during which 49 residents of the village were shot dead. Following this incident, the communists mobilized Yeshayahu Leibowitz's (in his religious thought he held that the essence of Judaism was practical commandments (mitzvot), and not faith) letter to the Ha'aretz newspaper. Leibowitz was an Israeli Orthodox Jewish intellectual and polymath who demanded that the soldiers who had committed the massacre be judged the same way Nazi soldiers were sentenced following the massacres they committed against Jews (Al-Ittihad: October 31, 1958). 
"Our country is the land of return and prophecy and is considered a lighthouse for the rest of the nations. There is no doubt that my proposals will find positive echoes among the readers. The redemption of Zion will be done only by good deeds and justice".

The above quotation is an example of cases where RT was used to emphasize rights and elimination of injustice, and especially as a tool for mediating between the Jewish majority and the Arab minority. The same phenomenon was observed in every incident of confrontation with the Israeli military or police forces, in which national sentiments arose among the Arab residents of Israel.

It should be noted that, at that time, the party's interests also set the tone and the relations between the two national groups, the Arab and the Jewish. The support for the Partition Plan by the Arab communists, after initially rejecting it, clarifies the fundamental significance of loyalty to the leadership of Soviet Union by the communists at that time and subsequently.

\section{Conclusions}

Throughout this paper, religious terminology (RT) was presented as a powerful tool that Arab communists could use, although they advocated an ideology of scientific atheism that was promoted by the Communist Party's ideological thinkers and leaders.

In an Islamic Middle East, where minorities enjoyed freedom of faith and worship, the secular atheism of Marxism did not penetrate the minds of the Arab communists in Mandatory Palestine and later in Israel; not even of those who had completed their academic studies at the Communist University of the Toilers of the East (КУТВ) in Moscow. Their religious education and culture prevented them from connecting to scientific atheism but did not prevent them from joining communism in the sense of practically realizing the religious values of social justice.

The Comintern, which promoted scientific atheism, together with the Palestinian Communist leaders, was aware of the fact that it would be hard to instill any modern or revolutionary socialism among a population of believers if it were to lack recognition of and reliance on religious foundations. For this reason the Arab communists, with the approval of the Comintern, often emphasized their religious identity and affiliation, in order to remove the atheist demon that clung to the ideology and to the superpower under which their party acted, and thereby succeed in advancing their political, class, and national interests. Nevertheless, throughout the party's different incarnations, total avoidance was practiced with regard to providing a platform for any religious discussion or emphasis of any religious orientation.

The Palestinian Arab communists knew that RT is a powerful tool that strikes emotional and sentimental chords among the masses. Therefore, they used it as a tool for national engineering; as a basis for establishing Communist ideology and instilling a Marxist education among the masses; to crown the Soviet Union and its leaders, instead of the religious leaders, as custodians of world order; to 
obtain legitimacy vis-à-vis the competing national parties; and to consolidate their status and attract the masses to the bosom of the party; to regulate relations within the party, including silencing any vagaries of opposition on the basis of ethnicity or social status; to blur any differences in religious identity of the Christian minority within the Muslim majority; to meditate and consolidate between and within the three systems: the Palestinian Arab ethno-national system, the broad system of the Arab and Jewish binational party, and the cosmopolitan system that identifies with communism.

The study showed that the use of RT played an ambivalent role in consolidating the Palestinian Arab collective under the ethno-national identity and in mediating with the communist Jewish collective, under the lateral cosmopolitan communist identity. Use of RT for the purpose of ethno-national consolidation was more direct and open, at a time when the Arab communists were free from partnership with the Jews within the party (in the Arabization period and the National Liberation League period) and more restrained and indirect during other periods, in which the Jews controlled the party (before the Arabization, and during the Maki period). The use of RT to consolidate with the communist and non-communist Jewish collective became more massive in circumstances when there was a need to ask the Arab masses' legitimization for joining a party with Jewish partners. Moreover, the frequency of the ambivalent use of RT as a tool for consolidating and mediating between the two ethnonational groups (the Arabs and Jews in Israel) increased when national sentiments became prominent against the backdrop of a direct national confrontation between the two collectives.

The study also showed that the Palestinian Arab communists adapted the use of RT to the circumstances of each period, which can be separated according to significant junctions (the establishment of the party; the Arabization process, the split of the party, the acceptance of the Partition Plan, the 1948 war, and the joining of the Israeli party), and as a response to the events of previous junctions. The following components dictated the change in the purpose of RT use between one junction and the next: the balance of power and relations with the Jews within the party and the composition of the party (bi-national/mono-national); the ethnic composition of the leadership; the competing forces of the traditional national movement; the policy of the Soviet Union regarding the relations within and outside the party; the strength and interests of the Soviet Union and its presence in the global space and in the surrounding Arab space; and the prominence of national sentiments in a time of confrontation or of direct or indirect war between the two national camps - the Arabs and the Jews.

\section{References}

Abu Khalil A (2009) Arab Communism: Some Reasons for Its Fall (Arabic). Angry Arab News. Retrieved from https://al-khbar.com/Archive_Articles/145790. [Accessed 13 January 2019].

Al-Karmil Newspaper. (Was a bi-weekly Arabic-language newspaper founded toward the end of Ottoman imperial rule in Palestine). The National Library of Israel. Retrieved 
from http://web.nli.org.il/sites/nlis/ar/jrayed/pages/press03-2017.aspx [Accessed 13 January 2019].

Al-Kaysi S (2012) The History of the Communist Party in Iraq from Fahd's Execution until the Revolution of July 14 1958. Damascus: Dar al-Hasad (Arabic).

Al-Sharif M (2006) Palestine in the Secret Archive of the Comintern. Damascus: Al Mada Publishing House (Arabic).

Appleby S (2012) Religious Violence: The Strong, the Weak, and the Pathological. Practical Matters 5: 1-25.

Baldwin D (1989) Paradoxes of Power. New York: Basil Blackwell.

Bamyeh M (2012) Intellectuals and Civil Society in the Middle East: Liberalism, Modernity and Political Discourse. London: I.B. Tauris.

Batatu H (1978) The Old Social Class and The Revolutionary Movement in Iraq. Princeton, NJ: Princeton University Press.

Ben-Zaken A (2006) Communism as Cultural Imperialism: The Affinities between EretzIsraeli Communism and Arab Communism 1919-1948. Tel-Aviv: Resling (Hebrew).

Dawkins R (1993) Viruses of the Mind. In B Dahlbom (ed) Dennett and His Critics: Demystifying Mind, 13-27. Hoboken NJ: Blackwell.

Dotan S (1991) Reds - The Communist Party in Eretz Yisrael. Kfar Saba: Shevna Hasofer (Hebrew).

Engels F (1880) Socialism: Utopian and Scientific. MECW Volume 24, pp. 457-9. First published: in F. Engels, Die Entwicklung des Sozialismus von der Utopie zur Wissenschaft, Hottingen-Zurich, 1882.

Engels F (1886) Ludwig Feuerbach and the End of Classical German Philosophy. In: Foreign Language Press Peking (1976). http://www.marx2mao.com/M\&E/LF86.ht ml. [Accessed 13 January 2019].

Fox J and Sandler sh (2004) Bringing Religion into International Relations. Culture and Religion in International Relations. New York: Palgrave Macmillan.

Fox J S (2018) An Introduction to Religion and Politics: Theory and Practice, $2^{\text {nd }}$ ed. New York: Routledge.

Froese P (2004) After Atheism: An Analysis of Religious Monopolies in the PostCommunist World. Sociology of Religion, 65(1): 57-75.

Froese P (2005) I Am an Atheist and a Muslim: Islam, communism, and ideological competition. Journal of Church and State 47(3): 473-501.

Ginat R (1996) Soviet Policy towards the Arab World, 1945-1948. Middle Eastern Studies 32(4): 321-335.

Ginat R (2008) Stages in the History of the Communist Movement in Egypt: The Jewish Perspective. Hamizrah Hehadash 47: 155-187 (Hebrew).

Ginat R (2011) A History of Egyptian Communism: Jews and Their Compatriots in Quest of Revolution. CO: Lynne Rienner Publishers.

Gramsci A (1971) Selections from the Prison Notebooks of Antonio Gramsci. New York: International Publishers.

Hart Ch (2011) Moving beyond Metaphor in the Cognitive Linguistics Approach to CDA: Construal Operations in Immigration Discourse. In: Hart, Ch. (Ed.), Critical Discourse Studies in Context and Cognition: 171-192. Amsterdam: John Benjamins.

Holsti O (1968) Content Analysis. In: Lindzey, G., Aronson, E. (Eds.), Handbook of Social Psychology, 2 : 596-692. Reading, MA: Addison-Wesley.

Jizmati N (2015) The History of the Arab Communist parties. Damascus: Dar Ninawa (Arabic).

Kabha M (2006) The Arab Press in Israel 1948-2006, as an Apparatus in the Identitybuilding Process. Sectoral Communication in Israel. Tel-Aviv University: Herzog Institute of Communications (Hebrew). 
Kabha M (2018) The Life of Jewish Immigrants from Muslim Countries in the Transit Camps as Reflected in the Arabic Journalistic Discourse in Israel, 1950-1967. Israel Studies at 70, Special Issue: Version and Reality 23(3): 123-131.

Krippendorff K (2004) Content Analysis: An Introduction to Its Methodology ( ${ }^{\text {nd }}$ ed). Thousand Oaks, CA: Sage.

Laughlin R, Pines D, Schmalian J, Stojkovic J, Wolynes P (2000) The Middle Way. PNAS 97(1): 32-37.

Lenin V (1905) Socialism and Religion. Collected Works 1965(10): 83-87.

Lozano S, Arenas A, Sanchez A (2008) Mesoscopic structure conditions: the emergence of cooperation on social networks. PLOS ONE 3(4): e1892.

Lowy M (1996) The War of Gods: Religion and Politics in Latin America. London-New York: Verso.

Lowy M (2005) Opium of the People? Marxism and Religion. International Viewpoint. Online Magazine of the Fourth International. Retrieved from http://www.interna tionalviewpoint.org/article.php3?id_article=807. [Accessed 8 January 2019].

Marx K (1844) Contribution to the Critique of Hegel's Philosophy of Law. in Karl Marx and Frederick Engels, Collected Works, volume 3. Retrieved from www.marxists. org/archive/marx/works/1843/critique-hpr/. [Accessed 8 January 2019].

McAnulla S (2012) Radical atheism and religious power: new atheist politics. Approaching Religion 2(1): 87-99.

Meyer M (2001) Between theory, method, and politics: positioning of the approaches to CDA. In R Wodak, M Meyer (eds) Methods of Critical Discourse Analysis. London: Sage McClelland.

Miron L (2011) A Red Star in the Israeli Flag: The Communist Movement in Eretz Israel and its Attitude Towards Zionism During the Yishuv and the First Decades of Independence. Jerusalem: The Hebrew University, Magnes Press (Hebrew).

Molyneux J(2008). More Than Opium: Marxism and Religion. International Socialism 119. Retrieved from www.isj.org.uk/?id=456. [Accessed 8 January 2019].

Rudnitzky A (2014) Arab Citizens of Israel Early in the Twenty-First Century. Tel-Aviv: The Institute for National Security Studies (Hebrew).

Said E (1994) Representations of the Intellectual. The 1993 Reith Lectures. New York: Pantheon Books.

Shanthi A, Kean Wah L, Laijum D (2015) Discourse Analysis as a Qualitative Approach to Study Information Sharing Practice in Malaysian Board Forums. International Journal on E-Learning Practices (IJELP) 2: 159-169.

Spiegel Y (2012) Agents of the criminal investigations department (CID) in the communist party. Iyunim Bitkumat Israel 12: 271-2.

Van Dijk T.A (2003) Critical Discourse Analysis. The Handbook of Discourse Analysis. 18: $352371 \mathrm{~W}$.

Vilner M (1970) 50 Years of the Communist Party in Palestine/Israel. Tel-Aviv: Central Committee, Communist Party of Israel (Hebrew).

Wodak R (2001) What CDA is about: a summary of its history, important concepts and its developments. In R Wodak, M Meyer (eds) Methods of Critical Discourse Analysis, 1-13. London: Sage.

Wright E (1978) Class, Crisis, and the State. London: New Left Books.

Zahavi L (2005) Apart or Together: Jews and Arabs in Palestine according to the Documents of the Comintern (1919-1943). Tel-Aviv: Keter Books (Hebrew). 


\section{$\underline{\text { Archives }}$}

Memorial and Heritage House archive, Nazareth, Israel (2019).

The National Library of Israel. Retrieved from https://bit.ly/2JnmbPZ [Accessed 8 January 2019]. 